\title{
Reflection on Coronavirus Accounting Impact on Small and Medium Sized Enterprises (SMEs) in Europe
}

\author{
Silvana Secinaro ${ }^{1}$, Davide Calandra ${ }^{1} \&$ Paolo Pietro Biancone ${ }^{1}$ \\ ${ }^{1}$ Department of Management, University of Turin, Turin, Italy \\ Correspondence: Davide Calandra, School of Management and Economics, Department of Management, Turin, \\ Italy. E-mail: davide.calandra@unito.it
}

Received: April 4, 2020

doi:10.5539/ijbm.v15n7p48
Accepted: May 26, 2020

Online Published: June 4, 2020

\begin{abstract}
This paper aims to carry out a systematic study on the effects in European small and medium-sized enterprises (SMEs). Financial Statement of the 2003 acute respiratory syndrome (SARS) epidemic to project the impact of the coronavirus on budgets. The financial statements of the European SMEs are examined, dividing them by geographical area and sector, comparing the performances of 2002 and 2003. The SMEs operate in the tourism and travel sectors. Changes may be seen in assets, capital, liabilities, and net profit. Furthermore, the paper analyzes the impact between the SARS epidemic and Financial Statement performance qualitatively. Then, according to content analysis, the effects on assets, liabilities, capital and net profit are estimated in the budgets of the SMEs following the coronavirus. The research argues that the magnitude of the impact of SARS on European SMEs was far less than what the main reports and analyses indicate. This experiment provides valuable lessons on predicting the budgetary consequences of future outbreaks, such as the ongoing coronavirus, and on the steps of control or prevention.
\end{abstract}

Keywords: accounting, budgeting, European SMEs, financial statements, financial performance, novel coronavirus, SARS, tourism

\section{Introduction}

Small and medium-sized enterprises (SMEs) are the backbone of any economy globally. They provide a potential source for economic growth. The European Commission defines a SME as a business with a workforce of fewer than 250 people (European Commission, 2020). They operate in all sectors of the economy. These businesses represent ninety-nine per cent of all business organizations within the European Union (European Commission, 2020). At the time of writing, there is an outbreak of a deadly new coronavirus known as COVID-19, which has the potential of affecting the balance sheets of SMEs, particularly those that operate in the tourism and travel sectors (Hoque et al., 2020). With its epicentre in Wuhan City in China's Province of Hubei, this contagious illness has now spread to over 40 countries around the globe (World Health Organization, 2020; Zhu, 2020). It is transmitted employing direct contact with respiratory droplets of a person who has contracted the disease generated when one sneezes or coughs (UNICEF, 2020). It is also transmitted when a healthy person touches surfaces that have been contaminated by this virus. A comparable disease that has occurred in the past is the Severe Acute Respiratory Syndrome (SARS), whose outbreak was in 2003, despite is lower spread than COVID-19 (Liu et al., 2020).

Starting from the reasoning of Hoque et al. (2020), this research study seeks to look into how SARS negatively impacted the balance sheets of several European SMEs to predict how SMEs today may be affected by the ongoing novel coronavirus. These companies include the TUI Group of Germany, EasyJet PLC of the United Kingdom, and Kuoni Travel of Switzerland. They are publicly listed small and medium-sized enterprises operating in various sectors, including tourism and travel. The financial statements of these SMEs are examined in this paper. This research study seeks to address the following research questions:

1. How did SARS 2003 impacts of businesses budgets in the tourism and travel sectors?

2. How will firms be able to limit the budgetary impact of the new COVID-19?

In general, this study is aimed at drawing attention to how global health problems impact the performance of SMEs in Europe. It has been previously reported in news outlets that the SARS epidemic of 2003 had a 
significant impact on SMEs. Various media companies reported in their print and broadcast media that many companies experienced a substantial adverse effect on their balance sheets as a direct result of SARS. Some authors also reported the same. For example, Lee and McKibbin (2004) reported that in the affected locations such as China, South Africa, Hong Kong, South America, and several European nations, businesses in the retail, travel, and tourism were significantly affected owing to people cancelling tourist trips. Even so, such claims were never verified by any research study. Moreover, the fact that many companies recovered quickly followed the end of the SARS outbreak implies that they were probably not adversely or significantly impacted by the epidemic. Since no study has ever been done in Europe to determine how companies on the continent were affected by the outbreak, this current research seeks to fill this literature gap. Therefore, the purpose of this study is as follows:

- To examine the effects of the 2003 SARS on the financial statements of European SMEs to project the potential impact of the coronavirus on the budgets of such companies today.

- To highlight how global health problems, impact the performance of European SMEs.

- To find out whether the novel coronavirus would adversely impact the financial performance of European SMEs.

- To provide policymakers with a reflection on the history of 2003, outlining future scenarios and choices to counter the blockage of the sector caused today by the COVID-19.

\section{Literature review}

\subsection{Outbreaks and Impacts on Business Performance}

The history of literature does not have a profuse strand of research on epidemic impacts in the economy. Events such as SARS or COVID-19 nowadays call the metaphorical definition of "Black Swan" (Aven, 2013) based on three main assumptions: an event out of expectations, with a strong impact, and that in retrospect is explained trying to predict its subsequent occurrence. These events for our human action represent an outlier, as they are for the reference literature. In order to investigate the impact on business performance of epidemics, reference should be made to SARS. More generally, the 2003 event had a direct impact, particularly on the tourism sector. As analysed by the contribution of Gupta et al. (2005), one of the measures that influenced the treatment process was the use of quarantine in order to stop the spread of the virus. Due to the rapid spread of SARS from Tawain to North America, companies have taken measures to stop the production and delivery of their services. Therefore, this had direct implications, especially on the value of tourism companies (Chen et al., 2007; Jayawardena et al., 2008). In particular, Chen et al. (2017) show how, due to the epidemic event, hotel companies suffered a sharp drop in profits and share prices throughout the period. More generally, Hai et al. (2004) show that the effects of SARS, although visible over a short period, had a direct impact in terms of loss of turnover for companies in the tourism and related sectors. This created a decrease in balance sheet values for the year 2003 and due to seasonality partly also for the following first quarter.

\subsection{Transmission Dynamics Model}

A conceptual framework that can help to understand the possible impacts of highly infectious disease on SMEs is the Transmission Dynamics Model. The theory was developed by El Turabi (2018). It is made of three elements: disease dynamics, transmission dynamics, and economic impact. The framework maintains that through vectors, the pathogen in a reservoir infects people, and this could cause an outbreak. The infection leads to a biological response, such as disease and patient fatality, which in turn have an effect on productivity and consumption in the long-term as well as short-term (El Turabi 2018).

Additionally, there is also a social responsibility to the infection outbreak from people. For instance, changing the patterns of travel to avoid regions that are prone to the disease; from governments, for instance, when they impose regulations and travel restrictions; and from non-government entities and private firms, which may withdraw their investment commitments (El Turabi, 2018). These responses, when taken collectively, result in substantial economic damages linked to the effect on both productivity and consumption. This economic impact, especially from social responses, is usually overlooked when analyzing the impacts of emerging infection outbreaks.

\subsection{Prevention Measures from SARS to COVID-19 as a Social Response}

There are several interventions that governments can take to prevent the spreading of the novel coronavirus. First is to quarantine people who have contracted the virus or who are suspected of having contracted it (Gupta et al., 2005). This facilitates close monitoring, treatment, and prevention of spreading. People who have travelled from COVID-19 prone-areas should also be advised by the government to self-isolate for at least 14 days to determine 
whether or not they have contracted the illness (Australian Government Department of Health, 2020). The second measure that governments can take is to find people who leave or enter outbreak areas. Those who violate quarantine rules should also be punished because they may spread it to other areas. The third intervention is to advise people to avoid very crowded places actively. This is a drastic measure that individual governments around the globe are already implementing. In South Korea, for example, joint annual South Korea and American military training were cancelled after several soldiers in the training camp contracted the virus, which has now infected over 1,780 in South Koreans (Ward, 2020). In Saudi Arabia, the government is restricting travel to Medina and Mecca, where Islam's very holy sites are situated. The temporary restriction is due to concerns regarding the further spreading of the disease. In Japan, the government has closed schools for one month to avert the spreading (Ward, 2020). Schools have also been closed in China, although daycare centres and universities remain open. In Europe, the Italian government has barred fans from attending live soccer matches in the country's top league, which now play in stadiums that are empty and is going to announce the total lockdown for non-essential activities (Tobìas, 2020). This is due to the fear that COVID-19 may spread through the crowd (Ward, 2020). Other governments in Europe should adopt such measures as this will help to prevent the outbreak from persisting for a long time and spreading even more, which could, in turn, have a more severe accounting impact on European SMEs.

Furthermore, SMEs can also implement interventions aimed at preventing the spread of the disease. One such intervention entails giving their employees protective face masks to prevent person-to-person transmission (Feng, 2020). This is important considering that such masks help to prevent infected people from spreading COVID-19 to those who have not yet contracted it (Australian Government Department of Health, 2020). Other interventions that SMEs can implement include encouraging their employees to always wash their hands regularly with water and soap after sneezing, coughing, or blowing the nose; before eating; and after visiting the bathroom (Cascella et al., 2020). They should also advise their employees who have been sickened by the disease to stay at home; healthy advice workers to avoid close contact with sick people; and cover their sneeze or cough with a tissue and discard it in the trash (Australian Government Department of Health, 2020). Employees should also be advised not to touch their mouth, nose, and eyes. Although all these elements are considered far from the corporate literature, as they are derived from the medical literature, they have been analyzed as elements that enter the dynamic model of transmission of changes in people's sociality and, consequently, firms.

\section{Methodology}

The research methodology selected for the current research study is document analysis. It is essentially a type of qualitative research wherein the researcher interprets documents to give meaning and voice around a particular assessment topic (O'Leary, 2014). It is notable that during the analysis of documents, the content is coded into themes just like how the transcripts of interviews or focus groups are usually analyzed. According to Bowen (2009), document analysis can be used in analysing a wide array of documents and records, including annual reports of companies. Since this research study seeks to analyze the annual reports of several European SMEs for the 2002 and 2003 Financial Years (FY), the document analysis methodology is appropriate.

Through the use of this methodology, the focus would be primarily on the balance sheets of three publicly listed European SMEs operating in the tourism sector. As reported by Hai et al. (2004) and Yang and Chen (2009), the sector has been one of the most affected by the past and given the current emergency, an analysis of past budgets is useful to learn how to manage what is happening today. Therefore, companies' balance sheets would be analyzed in detail. To implement the analysis, researchers adopted the content analysis process with three steps: preparation, organization and concluding (Elo \& Kyngäs, 2008). In the preparation phase, researchers focused on the selection of the company sector. The organization phase allowed us to focus on the asset, capital, liabilities, and net profit of these companies, as reported in the financial statements. The analysis of the balance sheets will begin from the effects of SARS on the balance sheet during the SARS period to establish what the effect was. Notably, the SARS epidemic occurred throughout the first half of 2003, although it began in late 2002 (Fan, Jamison \& Summers, 2018).

For this reason, there is the likelihood that the financial performances of some companies were affected in 2003. By analyzing the balance sheets of the selected companies for the 2002 Financial Year and 2003 Financial Year, it would be possible to estimate how the SARS disease affected the net profit, capital, liabilities, and assets of those European SMEs. Finally, in the concluding phase, the information set created and the conditions examined will help in reading the current COVID-19 situation, which is now a global epidemic, may impact the net profit, capital, liabilities, and assets of small and medium-sized businesses, particularly those in the tourism and travel sectors, around the globe. 
There are quite a few things that have to be done by the researcher before performing the actual document analysis. Firstly, a listing of the texts or documents to be explored should be created. Secondly, any biases in the text should be acknowledged and appropriately addressed (O'Leary, 2014). For annual reports of the SMEs that would be used in this study, the bias in the financial statements would be checked by determining whether the balance sheets were edited, are accurate, and establishing whether they are from a firsthand source, namely the company itself, or from a second-hand source, namely other entities other than the company. Thirdly, the researcher has to develop suitable skills for conducting research (O'Leary, 2014). Fourthly, strategies for ensuring credibility have to be considered. Fifthly, the researcher needs to understand the data that he or she is searching for.

Furthermore, ethical issues such as respecting confidential documents have to be considered. Starting from the discussion of Beutels et al. (2009), we considered in the sample companies that, although within the same sector, produce different goods and services and that concern leisure, national and international transport and tourist reception facilities. Lastly, the researcher should have a backup plan (Bowen, 2009). By taking into consideration these steps when using the document analysis method, the balance sheets of the selected companies would be analyzed effectively.

Finally, using the dynamic transmission model (El Turabi, 2018), researchers will analyse the possible responses of companies in order to limit the economic damage of companies in the sector.

\section{Results}

\subsection{TUI Group}

TUI Group, short for Touristik Union International, is based in the German city of Hannover. This multinational tourism and travel firm owns and operates cruise ships, airlines, travel agencies, and even hotels (TUI Group, 2004). It operates in three main regions of Europe: the Western Region comprising tour operations in France, the Netherlands, and Belgium; the Central Region comprising tour operations in Poland, Switzerland, Austria, and Germany; and the Northern Region comprising tours in the Nordics, Ireland, and the United Kingdom (TUI Group, 2004). An analysis of its financial statements for the 2002 and 2003 Fiscal Year (FY) is summarized in Table 1 below:

Table 1. Financial Performance of TUI Group in 2002 and 2003 (TUI Group, 2004)

\begin{tabular}{lll}
\hline & $2003 \mathrm{FY}$ & $2002 \mathrm{FY}$ \\
\hline Turnover & $€ 19,215$ million & $€ 20,302$ million \\
Total Assets & $€ 12,989$ million & $€ 15,517$ million \\
Capital Expenditure & $€ 1,063$ million & $€ 724$ million \\
Total Equity and Liabilities & $€ 12,989$ million & $€ 15,517$ million \\
Net Profit for the year & $€ 315$ million & $€ 41$ million \\
Earnings before interest, tax, depreciation & $€ 1,713$ million & $€ 1,501$ million \\
and amortisation (EBITDA) & $€ 902$ million & $€ 1,391$ million \\
Cash Flow from operating activities & & \\
\hline
\end{tabular}

As depicted in Table 1, a comparison of the financial performance of the TUI Group in 2002 and 2003 suggests that the company did not suffer significantly as a result of the 2003 SARS outbreak. Total Assets, Cash Flow, Total Liabilities, and Turnover decreased slightly in 2003 compared to 2002. At the same time, though, the company's Net Profit increased considerably from $€ 41$ million in 2002 to $€ 315$ million in 2003 (TUI Group, 2004). This implies that the outbreak of SARS in 2003 had only a slight impact on the balance sheet of this company. It is explained by a policy of diversification of the company visible by analyzing the report of the financial statements which sees the company active in offering differentiated tourist services in different locations around the world (TUI Group, 2004). Additionally, the analysis of the content of the intangible assets section shows that its intangible resources primarily determine the business. As can be seen from the report, the launch of the new logo on the market three years and the increased investments in the creation of websites and individual brands may have led to a closer identification of the customer with the services offered.

\subsection{EasyJet PLC}

This company operates in the travel sector. It is a point-to-point, low-cost European airline (EasyJet, 2020). The companies headquarter is located in London, England. Its financial statements for 2002 and 2003 were analyzed 
and the following table shows a summary of some of the items in its balance sheet.

Table 2. EasyJet financial statements for 202 FY and 2003 FY (Investegate, 2003)

\begin{tabular}{lll}
\hline & $2003 \mathrm{FY}$ & $2002 \mathrm{FY}$ \\
\hline Turnover & $£ 931,8$ million & $£ 551,8$ million \\
Total Assets & $£ 758,461$ million & $£ 727,704$ million \\
Capital Expenditure & $£ 98,485$ million & $£ 97,919$ million \\
Total Equity and Liabilities & $£ 42,869$ million & $£ 28,399$ million \\
Net Profit for the year & $£ 96,3$ million & $£ 90,2$ million \\
Earnings before interest, tax, depreciation & $£ 180,9$ million & $£ 132,4$ million \\
and amortisation (EBITDA) & $£ 77,231$ million & $£ 84,231$ million \\
Cash Flow from operating activities & $£$
\end{tabular}

EasyJet PLC was also not adversely affected by the 2003 SARS outbreak. As illustrated in Table 2 above, the company's Revenues, Assets, and Capital increased in the 2003 Financial Year compared to the 2002 Financial Year. Its Net Profit also went up, from $£ 90.2$ million in 2002 to $£ 96.3$ million in 2003 (Investegate, 2003). As such, EasyJet's balance sheet was not impacted by the SARS disease. In this case, it is explained by the policy of the markets served by the company and the level of uncertainty that has had less impact in certain areas. At the same time, during the epidemic period, the level of investments in marketing activities do not decrease.

\subsection{Kuoni Travel}

Another major player in Europe's tourism sector is the Swiss company Kuoni Travel Holding Limited. This SME has its headquarters are located in Zurich, Switzerland. The firm was founded by Alfred Kuoni in the year 1906 (Kuoni Global Travel Services, 2020). The company operates in three main business areas: Business Travel; Leisure Travel, which focuses on travel coordination activities; and Incoming Services, which offers destination services.

Table 3. A summary of the financial performance of Kuoni Group in 2002 and 2003 (Yumpu, 2003)

\begin{tabular}{lll}
\hline & 2003 FY & 2002 FY \\
\hline Turnover & CHF 3.295, 44 & CHF 3.739, 30 \\
Total Assets & CHF 1.839,57 & CHF 1.956,75 \\
Capital Expenditure & CHF 1.839, 57 & CHF 1.956,75 \\
Total Equity and Liabilities & CHF 64,64 & CHF 26, 22 \\
Net Profit for the year & CHF 102, 37 & CH 120, 66 \\
Earnings before interest, tax, depreciation & CHF 74, 37 & CHF 159, 19 \\
and amortisation (EBITDA) & CHF 3.295, 44 & CHF 3.739, 30 \\
Cash Flow from operating activities &
\end{tabular}

As shown in the table above, Kuoni Travel's Turnover and Total Assets reduced slightly. However, its Net Profit increased in 2003 as compared to 2002. This implies that the SARS outbreak of 2003 did not affect its balance sheet considerably. Also, in this case we consider that the company's diversification policies have had a positive effect in keeping the balance sheet values at the end of the year under study (Kuoni Global Travel Services, 2020).

\section{Discussion}

In this research, the financial statements of three European SMEs operating in the tourism and travel sectors were analysed in detail. The analysis focused on the impact of the 2003 SARS epidemic on the financial performance of the SMEs, which included companies based in different regions of Europe, from Germany in Central Europe to Switzerland in Western Europe, and the United Kingdom in Northern Europe. The results indicate that the magnitude of the impact of the 2003 SARS epidemic on SMEs in Europe is significantly less than what reported in the Asian a Northen America area (Chen et al., 2007; Jayawardena et al., 2008). Each of the three companies whose financial statements were analyzed in this paper has a famous brand of services and continuing to communicate with their customers, also during the epidemic event. The famous brands may have prevented these companies from suffering significantly during the SARS crisis by attracting more local or domestic customers as the numbers of foreign customers dwindled. For Kuoni Travel, its highly popular 
Helvetica brand, which includes discount travel and tour operations, may have been indispensable in helping the firm to continue attracting tourism at the time. For EasyJet PLC, its famous brands such as EasyHotel, EasyGym, EasyLimousines, EasyCar, EasyFoodstore, EasyEnergy, EasyVan, EasyCoffee, EasyAir, and EasyBus may have helped to prevent substantial losses when international travellers declined in number. For TUI Group, its popular brands including SplashWorld Resorts, TUI Lakes \& Mountains, Crystal Ski Holidays, and First Choice helped to cushion any losses. In essence, these SMEs suffered less because customers had trust in these popular brands despite the SARS outbreak at the time.

It is worth mentioning that SARS spread into only 29 countries. It infected about 8,000 people, and 774 people died as a result (Fan, Jamison \& Summers, 2018), which is a small number compared to the novel coronavirus which has now spread to more than 50 countries, infected over 78,000 people, and killed over 2,800. Besides, SARS was over within just six months. Therefore, the fact that the SARS outbreak did not last for a long time, and not many people have infected means that its adverse impact on businesses was also not substantial. However, if SARS would have infected more people in more countries, people would have changed their travel patterns and travel less ( $\mathrm{Zu}, 2020)$, which might have had a considerable impact on SMEs.

These findings are consistent with the theoretical framework, namely the Transmission Dynamics Model, which maintains that the outbreak of an infectious illness could result in a social response from people. In essence, individuals will alter their traveling patterns to avoid going to areas prone to the disease, governments will impose regulations to help contain the spread of the infection, and businesses will rescind their investment commitment (El Turabi, 2018). Such responses could bring about economic losses to SMEs in travel and tourism in Europe. Even so, El Turabi (2018) also mentioned that a large portion of the economic losses that occur in a country or region is mainly related to costs of taking care of the patients affected by the disease as opposed to losses posted on balance sheets.

Comparing the economic impact of the Zika virus in South America and Ebola in West Africa using the Transmission Dynamics Model, El Turabi (2018) pointed out that the overall economic impact of an epidemic on businesses and a country's economy is dependent upon disease dynamics. This theorist provided case studies of the economic impacts of the Zika epidemic in 2017 and the Ebola epidemic in 2016. According to him, the disease dynamics of Zika could be described as a slow burn, whereas he described Ebola as a raging forest fire (El Turabi, 2018). More people were infected with the Zika virus than by Ebola, although the clinical syndrome of Zika is a lot less severe in the acute phase. It is worth mentioning that the difference in a fear-induced by Zika and Ebola was a critical qualitative factor in comparing the two illnesses. The different characteristics of these two very infectious illnesses explain the different behavioural responses and economic impacts that the two illnesses generate. Even after a rather modest event, there is a trend of substantial economic losses (El Turabi, 2018). It is right and demonstrated by Hai et al. (2004). Similarly, the fear induced by the SARS pandemic of 2003 and, currently, the fear induced by the COVID-19 disease is critical factors in comparing the two infectious diseases, including their accounting impact on European SMEs in various sectors. It will be outstanding after this period to analyse how companies face in front of this pandemic period.

Disease risks are affected by, and also affect, the decisions that people make. This creates a feedback loop in which the levels of infections drive human behaviours and decisions that humans make shape the spread of diseases. These human conditions, as Fenichel et al. (2015) pointed out, are determined by trade-offs when people take into consideration the scarcity of resources such as money and time. Although individuals may value their health status, they may as well value work, relationships, family, and social activities which affect their decision-making and their exposure to contagious illnesses (National Academy of Sciences, 2020). With these different sources of trade-offs, individuals could alter their behaviours in response to changing circumstances and their decisions are founded upon the best available information (National Academy of Sciences, 2020).

Concerning the SARS outbreak of 2003, some people, who were the potential customers for European SMEs in the travel and tourism sectors, might have changed their behaviours in response to the changing circumstances surrounding the outbreak of the disease and their decision to change their behavior was based upon the information that they received mainly from the media, experts, and their embassies (Fan, 2003). The change in behavior, which included limiting their travel to countries and areas where the disease was prone, explains the difference in the balance sheet figures as the SMEs may have experienced some reduced economic activities. For example, TUI Group posted a Turnover of $€ 19,215$ million in 2003, which was a drop from $€ 20,302$ million in 2002. Kuoni Travel also posted reduced Turnover, which fell from CHF 3,739, 298 in 2002 to CHF 3,295,436 in 2003. Its Total Assets also declined from CHF 1,956,753 in 2002 to CHF 1,839,572 in 2003. These slight declines might have been as a result of reduced travel as people changed their travel patterns in 2003. 
Generally, when people stop travelling or reduce their travelling owing to panic or fear of contracting a disease, the impact on companies that depend on people travelling to make their revenues and revenues, such as tour operator companies, holiday resorts, and legacy and low-cost carriers, could be significant. Even so, the extent of the accounting impact is, to a large extent dependent upon the persistence and duration of the outbreak. This implies that the longer and the more persistent the outbreak is, the more significant the impact would be (Fan, Jamison \& Summers, 2018). The impact of 2003 SARS disease on the balance of the selected European SMEs in the tourism and travel sectors was not as significant as earlier thought, mainly because the disease outbreak lasted for only about six months. In essence, the SARS outbreak occurred in the first half of 2003 and businesses rebound in the second half as economic activities increased to make-up for the loss that occurred in the first half (Fan, 2003). As a result, the European SMEs did not suffer substantially in the 2003 Financial Year as indicated by the analysis of their balance sheets. This effect, on the other hand, has been opposed in the areas where SARS is most widespread, so we believe that the discussion of the dynamic transmission model can be useful and put into service to read what is happening to the European tourism market (Chen et al., 2007; Jayawardena et al., 2008).

The implication of this research study, without any presumption of statistical evidence, is that it offers valuable lessons for potential budgetary effects of future outbreaks of deadly infectious diseases such as the ongoing COVID-19 illness. If the outbreak of this coronavirus disease persists for an extended time, for instance for over six months, and if it spreads to many more countries and locations globally, causing fear and panic and continuation of travel restrictions, its accounting impact on SMEs in the travel and tourism sectors would be significant (Wang, 2020). On the other hand, the impact on the balance sheet of the SMEs would be quite negligible if the disease lasts for only a few months and then businesses recover quickly afterwards. This underscores the need for speedy action by both government and non-governmental entities to contain its spread.

\section{Conclusion}

The ongoing COVID-19 crisis is more or less comparable to the 2003 SARS epidemic. The crisis can potentially impact the financial performances of SMEs. This study sought to investigate the effects of the 2003 SARS on the financial statements of several European SMEs so as to highlight how the coronavirus will impact on the budgets of such companies today. Three SMEs were selected as part of the research: TUI Group of Germany, EasyJet PLC of the United Kingdom, and Kuoni Travel of Switzerland. The methodology utilized entailed document analysis, in which the financial statements of these three companies were analyzed to determine whether SARS had an effect on their assets, liabilities, profits, and capital. The findings demonstrate that the magnitude of the impact of the SARS epidemic in 2003 on SMEs in Europe is much less than what was reported in the news at the time. In essence, the impact of SARS on the three SMEs was negligible. It is because the SARS outbreak did not last long; it was over within six months. If COVID-19 persists for only a short period of time, its impacts on SMEs would be small. On the contrary, the accounting impact on European SMEs would be immense if it persists for many months. What we could observe from the selected sample is that we hope it will provide implications for managers during this period is that the selected companies have continued their customer support activities with ongoing marketing and communication of their brand value even during the darkest periods of the epidemic.

\section{References}

Aven, T. (2013). On the meaning of a black swan in a risk context. Safety science, 57, 44-51.

Australian Government Department of Health. (2020). Coronavirus (COVID-19). Retrieved from https://www.health.gov.au/health-topics/novel-coronavirus-2019-ncov

Beutels, P., Jia, N., Zhou, Q. Y., Smith, R., Cao, W. C., \& De Vlas, S. J. (2009). The economic impact of SARS in Beijing, China. Tropical Medicine \& International Health, 14, 85-91.

Bowen, G. A. (2009). Document analysis as a qualitative research method. Qualitative Research Journal, 9(2), 27-40. https://doi.org/10.3316/QRJ0902027

Cascella, M., Rajnik, M., Cuomo, A., Dulebohn, S. C., \& Di Napoli, R. (2020). Features, evaluation and treatment coronavirus (COVID-19). In Statpearls [internet]. StatPearls Publishing.

Chen, M. H., Jang, S. S., \& Kim, W. G. (2007). The impact of the SARS outbreak on Taiwanese hotel stock performance: an event-study approach. International Journal of Hospitality Management, 26(1), 200-212.

EasyJet. (2020). What we do. Retrieved from http://corporate.easyjet.com/about/what-we-do 
El Turabi, A. (2018). Assessing economic vulnerability to emerging infectitious disease outbreaks: Ebola versus Zika. National Academy of Medicine Forum on Antimicrobial Threats. Harvard Business Review.

Elo, S., \& Kyngäs, H. (2008). The qualitative content analysis process. Journal of advanced nursing, 62(1), 107-115.

European Commission. (2020). Small and Medium-Sized Enterprises (SMES). Retrieved from https://ec.europa.eu/eurostat/web/structural-business-statistics/structural-business-statistics/sme

Fan, E. X. (2003). SARS: Economic impacts and implications. Manila, Philippines: Asian Development Bank.

Fan, V. Y., Jamison, D. T., \& Summers, L. H. (2018). Pandemic risk: How large are the expected losses? Bulletin of the World Health Organization, 96, 129-134.

Fenichel, E. P., Castillo-Chavez, C., Ceddia, M. G., Chowell, G., Parra, P. A. G., Hickling, G. J., Holloway, G., Horan, R., Morin, B., Perrings, C., Springborn, M., Velazquez, L., \& Villalobos, C. (2015). Adaptive human behavior in epidemiological models. Proceedings of the National Academy of Sciences of the United States of America, 108, 6306-6311.

Feng, S., Shen, C., Xia, N., Song, W., Fan, M., \& Cowling, B. J. (2020). Rational use of face masks in the COVID-19 pandemic. The Lancet Respiratory Medicine.

Gupta, A. G., Moyer, C. A., \& Stern, D. T. (2005). The economic impact of quarantine: SARS in Toronto as a case study. Journal of Infection, 50(5), 386-393.

Jayawardena, C., Johnson Tew, P., Lu, Z., Tolomiczenko, G., \& Gellatly, J. (2008). SARS: lessons in strategic planning for hoteliers and destination marketers, International Journal of Contemporary Hospitality Management, 20(3), 332-346. https://doi.org/10.1108/09596110810866145

Hai, W., Zhao, Z., Wang, J., \& Hou, Z. G. (2004). The short-term impact of SARS on the Chinese economy. Asian Economic Papers, 3(1), 57-61.

Hoque, A., Shikha, F. A., Hasanat, M. W., Arif, I., \& Hamid, A. B. A. (2020). The Effect of Coronavirus (COVID-19) in the Tourism Industry in China. Asian Journal of Multidisciplinary Studies, 3(1), 52-58.

Investegate. (2003). EasyJet PLC: 2003 preliminary results. Retrieved from https://www.investegate.co.uk/article.aspx?id=200311180700321726S

Yang, H. Y., \& Chen, K. H. (2009). A general equilibrium analysis of the economic impact of a tourism crisis: A case study of the SARS epidemic in Taiwan. Journal of Policy Research in Tourism, Leisure and Events, 1(1), 37-60.

Kuoni Global Travel Services. (2020). History of Kuoni Global Travel Services. Retrieved from https://www.kuoniglobaltravelservices.com/about-us.asp

Lee, J. W., \& McKibbin, W. J. (2004). Globalization and disease: The case of SARS. Retrieved from https://www.brookings.edu/research/globalization-and-disease-the-case-of-sars-2/

Liu, Y., Gayle, A. A., Wilder-Smith, A., \& Rocklöv, J. (2020). The reproductive number of COVID-19 is higher compared to SARS coronavirus. Journal of travel medicine.

National Academy of Sciences. (2020). Understanding the economics of microbial threats: Proceedings of a workshop. Retrieved from https://www.nap.edu/read/25224/chapter/5

O'Leary, Z. (2014). The essential guide to doing your research project (2nd ed.). Thousand Oaks, CA: SAGE Publications, Inc.

Pine, R., \& McKercher, B. (2004). The impact of SARS on Hong Kong's tourism industry. International Journal of Contemporary Hospitality Management.

Tobías, A. (2020). Evaluation of the lockdowns for the SARS-CoV-2 epidemic in Italy and Spain after one month follow up. Science of The Total Environment, 138539.

TUI Group. (2004). Annual Report 2004. Retrieved from https://www.tuigroup.com

UNICEF. (2020). Novel coronavirus (COVID-19) outbreak: What you should know. Retrieved from https://www.unicef.org/indonesia/novel-coronavirus-covid-19-outbreak-what-you-should-know

Wang, C. (2020). A novel coronavirus outbreak of global health concern. PIIS, 10(20): 85-89. 
Ward, A. (2020). Closed schools and empty stadiums: How countries are trying to stop coronavirus's spread. Retrieved https://www.vox.com/2020/2/27/21155864/coronavirus-italy-saudi-arabia-south-korea-japan-military

World Health Organization. (2020). Coronavirus disease (COVID-19) oubreak. Retrieved from http://www.euro.who.int/en/health-topics/health-emergencies/coronavirus-covid-19/novel-coronavirus2019-ncov

Yumpu. (2003). Kuoni Group 2003 financial report. Retrieved from https://www.yumpu.com/en/document/read/4986501/financial-report-2003-english-pdf-aaa-28726-kb-k uoni-group/47

Zhu, N. (2020). A novel coronavirus from patients with pneumonia in China. N Engl J Med, 20(8), 727-733.

Zu, Z. Y. (2020). Coronavirus disease 2019 (COVID-19): A perspective from China. Radiology, 12(41), 95-99.

\section{Copyrights}

Copyright for this article is retained by the author(s), with first publication rights granted to the journal.

This is an open-access article distributed under the terms and conditions of the Creative Commons Attribution license (http://creativecommons.org/licenses/by/4.0/). 